\title{
Analysis on Folk Music Teaching Problem and Its Solutions
}

\author{
Yi Ji \\ School of Music and Dance \\ Qujing Normal College \\ Qujing, Yunnan, China 655011
}

\begin{abstract}
As China's economy continues to develop, it has formed a long-term conflict between the people's cultural requirements and cultural productivity. Development of folk music culture of our country needs to reform and innovation to another level. There are still many problems in Folk Music Teaching in our country, such as backward teaching methods, improper specialty setting, they have became an important constraint factor for Folk Music teaching Development. Therefore, how to promote the deep reform of folk music teaching development from all aspects, is a problem that we and the whole China need serious consideration. This article will elaborate existing problems and corresponding measures from various aspects of the system of National Folk Teaching.
\end{abstract}

Keywords—nation; folk culture; music; teaching; reform

\section{INTRODUCTION}

China is a country with a history of 5,000 years of civilization, in the past feudal dynasty, it created a long history of civilization relying on continuous integration of 56 ethnic groups and their own unique charm. Folk music is one of a precious pearl. The different nations have created their colorful folk music culture, and now it is up to us the future generations to develop and innovate it, so that folk music culture could passing the torch, so to enhance people's national pride and national self-confidence and strengthen our national cohesion.

\section{The BASIC PROBlem OF CURRENT FolK MusiC} TEACHING

\section{A. Outdated and Single Teaching Methods, Lag Teaching Medium}

Folk music has always use the traditional teaching methods continue teaching, this teaching method is not only old, but also teaching methods are very simple. It simply instills book knowledge into the pupil's brain. The reason why ancient folk music can last until today is because teaching methods is always changing with the times changing, but in the process of classroom teaching that spirit is slowly fade, not only fade, but also in intensified tampering folk music proper teaching methods. It leads to the whole folk music teaching methods in China are very backward, not able to adapt to the times development and also not able to meet the realistic demands for folk music Cultural Development required by the era. Along with outdated and simple teaching methods, it shows another phenomenon. With the development of society and economy, folk music media carrier already converted from the past by person into the present music media, teaching methods lag caused many people lose their interest in learning folk music culture. It is also one of the important reasons why folk music culture is difficult to promote. Due to stick to a book, make the class as an important place for further studies, also put music learning into the entrance examination system, so that students have forgotten the charm of folk music, they simply learning for learning. Teaching music and cultural knowledge slowly floating to the surface, theory has a serious gap with practice, which is also an important factor in China caused Folk Music Culture decline.

\section{B. Only Talk without Practice, Lack of Practice,Theory Divorced from Reality Seriously}

In the process of the past folk music teaching, teachers stick to the books and put the entire class on top of the books, so that students lose the opportunity to experience the charm of folk music culture. Folk music culture is created by the masses, is the ethnic essence summed up in a few thousand years of labor practice, it is an important weapon to improve the cohesion of the nation. But such a national treasure has gradually lost his glory on student's class and slowly becoming an important tool for students to further studies. Theoretically folk music culture simply can not let students learn, only practice is the true origin of understanding of the folk music culture. Blindly emphasized that students learn theory, only will make students fall into the knowledge trap and gradually forget how to learn the real knowledge from practice. In the past our Chinese nation has made brilliant achievements in the creation of our culture and summed up the national spirit crystal by their wisdom after untold hardships. It all needs practice to have deep experience. Folk music can not be shelved in books, and it can not become capital for students to get further studies. The folk music has to be practiced and specified. It needs further practice. But now the situation is teachers divorced from reality seriously, only teach the book knowledge of folk music culture to the students, did not help the students to understand these cultures deeply. Therefore a serious gap between the theory and the reality is resulted. 


\section{Weak Teachers, Lack of Folk Music Culture Teaching Personnel}

Although many schools have set relevant professional folk music culture major, but because students are not much, which led to the relevant university faculty in the major is very weak. This is not just the structure of the faculty but also the number of relevant professional instructors. First in structure, no matter junior high school, high school or universities, they only hair folk music teachers with overseas education background, for domestic teachers, they at least need to be postgraduate from 985 or 211 colleges and universities. For those postgraduate or aboard study teachers, they do not have much chance to contact with folk music, not to mention the return of overseas teachers is simply not in contact with China's national music culture; Also in the current folk music culture teachers, a considerable part of them is nearing retirement but haven't yet find a suitable successor, they can only wait for his successor to take over the related work. On the other hand, the number of folk music teacher is also small, the school is now almost everywhere, the scale of China's education gradually ranking in the world, but the number of folk music teacher is always small due to various reasons. Weak teachers are reflected in these two areas. Not only from the current situation, there are still future embarrassment, according to statistics, the relevant professional folk music culture major will be less and less in the future in some major universities, some may even cancel the folk music major or merge it with other majors. Educational institutions at all levels are also possible to cancel the Folk Music Culture class, which directly led to the rare of folk music culture teaching personnel.

\section{The Lack of Professional Audio-visual Teaching Materials on Folk Music Culture}

The lack of professional audio-visual teaching materials on folk music culture is happened in many schools. The reason for this happens is nothing more than the following reasons: First, folk music culture spread itself is not attract the attention from education department, this is the old news, we can see in schools, folk music teaching instruments were mostly ordered when the school established, these musical instruments can not adapt to the development of the times after all these years, use these old equipment for teaching can not make students feel the unique charm of folk music, but because the old equipment can not show the real romantic of folk music, it will kill the students' interest instantly. Second is about the school's audiovisual teaching materials, most of the materials played directly in school without update, it is hard to understand the content and for many teachers, they are not willing to play it. For this situation going on, students' enthusiasm for folk music is also faded by day. In addition, audio-visual teaching materials are preferably requires first-hand information, but many schools downloaded the secondary data from Internet, not only with poor quality, and may be downloaded piracy materials, it may cause copyright infringement and bad teaching result. It can be said, old folk music teaching instruments and old audio-visual materials from old schools to some extent hindered the normal development of folk music teaching.
The above questions are very good description of some of the problems at present with Chinese folk music culture spread, not only in some areas, but due to China's basic national conditions. But now time is developing and the economy is developing too, if these problems still exist, it will block the healthy development of the national society. The above problem is not only restricted the teaching reform of the folk music culture, but also seriously reduce the interest in learning the national folk music culture. The specific ideas about Folk Music Culture Teaching Reform

\section{E. Increase Class Teaching Reform, Innovative Teaching Methods, Build A New National Folk Music Teaching Mode}

1) Enhance students' interest in learning folk music, let students to actively participate in music teaching reform: During the folk music culture spread process, schools and other educational institutions are the main active positions, but the students are the key role. We should allow students take the initiative to participate in music education reform no matter in class or in practice and let them play a proactive and constructive role, this will allow National Folk Music Teaching Reform implement deeper and more thorough. First, in class, teachers should guide students to show their initiative in learning, students are encouraged to fully participate in and exploit their strengths, find their own difference. Folk Music teaching class will not only be the music teaching place but also a stage to enhance self-worth, so that everybody is encouraged to the stage and show themselves and make selfrelease. This approach not only can improve the students' enthusiasm for learning, but also to promote national music teaching reform in campus in certain extent. Also in practice, teachers should play their own active role in practice, in the past teacher is exists as a behavior guidance and for today's world which advocate the practice, it should be like this too. In practice, teachers can teach students in the past how does Chinese nation created these nationals treasures by their wisdom under such a difficult environment. Teachers should also set an example, take the lead in efforts to study folk music culture in order to make better teaching in practice.

In Folk music teaching class, teachers can also show students a variety of ancient musical instrument or more beautiful folk music instruments with their own advantages. Have students choose to study according to their own interests or experience, the benefits of this is it will not only allow students to have close contact with folk music, also allow students to have a deeper understanding with folk music from another level. Through learning the profound folk music, also indirectly improve your own cultural and professional qualities.

2) Fully use modern information technology, multimedia and other advanced technologies combined with teaching: With the social and economic development, the development of science and technology, communication means of folk music culture also have certain development, but in the past majority school's teaching methods are simply relying on the books as a medium of teaching, in this way teaching is boring with no interest and also seriously undermine the students' interest in learning folk music, which is not a good thing for both teaching and learning parties. In the modern folk music 
teaching we should use internet resources for teaching, on one hand we could communicated and cooperate with national folk music professional experts and establish long-term cooperative partnership with them; on the other hand, we can contact with the relevant foreign-related workers, combine the foreign teaching methods together with China's basic national conditions and innovate new teaching methods. At the same time teachers can make multimedia files to vivid reproduction of the situation and through sophisticated audio and video to bring students into another era. With real historical data to give students a strong visual impact, let them deeply feel and experience folk music culture and establish deep sense of identity from the heart about national music culture.

\section{F. The Establishment of Relevant Teaching Experimental Base, to Strengthen Relevant Cooperation with National and Folk Music Groups}

We all know folk music is originated among the people so naturally in the teaching process, we can not forget the folk music group or nation's great achievements ,so in the process of education reform we must continue to make further cooperation with the folk music group and form a long-term cooperative relationship. Together we will make deep study on how should folk music's deep heritage develop in the future and how to make innovative development. It also should establish relevant teaching and experimental base in each area where educational institution is located. The based is used for the study of Folk Music Teaching Reform and future development mode of folk music. The advantages of this is that on one hand it is able to combine successful practical experience from folk music group together with actual situation of the school, so to develop innovative classroom teaching, also allow students to experience a diversified folk music teaching; on the other hand it can always keep in touch with folk music groups so you can keep understand the development situation of folk music and help each other to continue the development of folk music.

\section{G. Increase Capital Investment for Folk Music Teaching and Research, Introduce New Resources and Improve the Overall Quality of Teachers}

Many schools have expressed their capital shortage for folk music teaching and research, which directly affects the teaching result, in such circumstances must focus on increase the capital investment for folk music teaching and research. Strengthen the construction of teaching hardware facilities and equipment. Purchase professional quality audio-visual teaching materials from multi-channel in order to solve the current embarrassment situation for folk music teaching from the hardware side. On the other hand also we should proceed from the overall quality of teachers, constantly evaluate the overall quality of teachers and arrange professional training to improve the professional quality. The introduction of new resources will keep the folk music teaching has sustained a normal healthy development.

\section{CONCLUSION}

Folk music course relates to a very wide range of fields with a broad development prospects, the whole country should be aware of the unshakable solid status in the historical process for the folk music culture which as a cultural crystal from thousand of years history, we need to constantly make innovation and reform to make folk music always maintain its vitality. In today's world integration process, it requires continuous attention from all sectors of society to join the common trend of the development of national folk music. As the main active position of folk music, it need to play a good and initiative role, only after the development and utilization of folk music teaching resources, so that folk music could meet the requirements of the existing reform framework of higher education, then it could training more and more professional musicians, so as to meet the needs of the evolving social processes, and ultimately enhance national cohesion and national self-confidence.

\section{REFERENCES}

[1] Xie Zheng Thoughts on Reform of National Folk Music Teaching [J] "Education and Career", 2006 (27): 88-89.

[2] Wang Haiyuan Multidimensional teaching of folk music courses under Modern Language [J] "Song of the Sea", 2008 (2): 42-43. 